Jurnal Teknologi Laboratorium

Vol.9, No.2, 2020, pp. 186 - 191

ISSN 2580-0191(Online), ISSN 2338 - 5634(Print)

DOI: $10.2938 /$ teknolabjournal.v9i2.235

Journal homepage: https://www.teknolabjournal.com/index.php/Jt//index

\title{
Original Research.
}

\section{Identification of molecular markers for type 2 Diabetes mellitus in Sidoarjo, Indonesia}

\section{Miftahul Mushliha, Fitri Kumala Sari ${ }^{b}$, Hindah Sabrina Amin ${ }^{c}$, Siti Asriani Iknan ${ }^{d}$}

Department Medical Laboratory Technology, Universitas Muhammadiyah Sidoarjo, Sidoarjo, Jawa Timur, Indonesia

a E-mail address: mif.mushlih@umsida.ac.id

bE-mail address: khumalasarifitri@gmail.com

cE-mail address: hindahsabrina@gmail.com

dE-mail address: asrianimoudy12@gmail.com

\section{HIGHLIGHTS}

Based on our study we found molecular markers to determine the likelihood of a person suffering from type 2 diabetes using the PCR-RAPD method

\section{ARTICLE INFO}

\section{Article history}

Received Date: Aug $17^{\text {th }}, 2020$

Revised Date: Nov 02 ${ }^{\text {nd }}, 2020$

Accepted Date: Nov 28 ${ }^{\text {th }}, 2020$

\section{Keywords:}

Diabetes mellitus

Genetic disorder

PCR-RAPD

Polymorphism

Molecular Marker

\section{A B S T R A C T}

T2DM can be triggered by two collaborating factors, namely genetics and the environment. This study aimed to identify genetic markers that can be used to detect the possibility of a person having T2D using the random amplified polymorphism DNA (RAPD) method. The study was carried out cross-sectional and involved 60 samples consisting of 30 positive T2D samples and 30 negative samples T2D. The primer used for PCR-RAPD was D20 (5'-ACCCGGTCAC-3'). The PCR-RAPD results were then analyzed using the scoring method and analyzed using the non-parametric Chi-Square test (cl: 95\%). Among T2D, 576 bp band were confirmed to be markers in the patients.

This is an open-access article under the CC-BY-SA license.

\section{*Corresponding Author:}

\section{Miftahul Muslih}

Jurusan Teknologi Laboratorium Medis, Fakultas IImu Kesehatan,

Universitas Muhammadiyah Sidoarjo, Indonesia

Email: mif.mushlih@umsida.ac.id

\section{INTRODUCTION}

Diabetes mellitus (DM) sufferers continue to increase. 463 million people suffer diabetes mellitus and it is estimated to increase to 578 million in 2030 and 700 million in 2045. Indonesia is the seventh most DM sufferer in the world. ${ }^{1}$ These conditions are very worrying

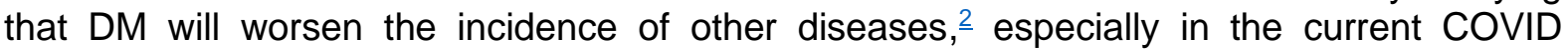
pandemic. -3 DM can be grouped into four categories, type 1 diabetes mellitus (T1D) which is a failure of insulin production and is usually congenital, type 2 diabetes mellitus (T2D) is an event that is more likely to be experienced by adults and is caused by genetic disorders and environmental factors. Gestational diabetes (GD) is usually owned by women who are pregnant, and the last is diabetes with other symptoms that may be caused by infectious disease syndrome of the pancreas or the use of drug substances in the case of HIV AIDS therapy or after organ transplantation. $4, \underline{5}$ 
T2D is characterized by increased levels of glucose in the blood due to the malfunctioning of cell receptors to enter insulin, several studies show that it followed by decreasing insulin production. $-\frac{6}{}$ T2D incidence can change the stability of body fluids. ${ }^{7,8}$ The complexity of T2D makes it difficult to control. 9 T2D is caused by genetic factors and environmental factors. Genetic factors are related to factors that cannot be changed and are inherited from both parents, while environmental factors are the factors that sufferers can manipulate, including changing social habits, especially due to lack of physical activity and excessive food consumption. 5,10

Analysis of the relationship between the effects of genetic mutations with T2D is widely carried out. More than 120 genes are involved and some are closely related. ${ }^{11,12,13,6,14,15}$ However, type $2 \mathrm{DM}$ is still difficult to control due to other factors that have a tendency such as obesity, ${ }^{16}$ ethnicity, ${ }^{17}$ and lifestyle changes. ${ }^{18}$

Previous analyzes regarding the identification of polymorphisms showed different polymorphisms between type $2 \mathrm{DM}$ and non-DM patients. ${ }^{19}$ PCR-RAPD has advantages such as simple, easy, inexpensive, does not require target gene analysis, and can analyze the whole genome. The purpose of this study was to determine specifically as a marker of the possibility of a person suffering from type 2 diabetes or not using primers that produce specific polymorphisms.

\section{MATERIAL AND METHOD}

This research method was cross-sectional with an exploratory descriptive. Sampling had approved by the ethical committee of dentistry, Faculty of Medicine, Airlangga University, Surabaya with number: 091 / HRECC.FODM / III / 2020. A total of 60 people consisting of 30 positive T2D and 30 negative T2D were used in this study. Sampling through macro sampling as much as $3 \mathrm{cc}$ is stored in the EDTA tube. Sampling was done by purposive sampling. The inclusion criterion for a positive sample was had diagnosed by a doctor or glucose test showed more than $200 \mathrm{mg} / \mathrm{dl}$ (random blood test). A negative sample is a subject that has less than $180 \mathrm{mg} / \mathrm{dl}$ in the glucose test. An interview was also given whether he had a family history of DM or not. If the sample had a family history of DM, the sample was canceled.

DNA isolation was carried out using the standard procedure of the GeneAid DNA Isolation kit for blood. The pure DNA was then analyzed quantitatively using a Thermo Evolution 201 spectrophotometer. PCR-RAPD was done using Bio-rad T100 thermocycler with $15 \mu \mathrm{L}$ total reaction (DNA Template $2 \mu \mathrm{L}$, Primer A10 $2 \mu \mathrm{L}$ (5'-ACCCGGTCAC-3 '), PCR Mix $5 \mu \mathrm{L}$, ddH2O $6 \mu \mathrm{L}$ ). The reaction was Pre-denaturation $94^{\circ} \mathrm{C}$ at 5 minutes, Denaturation $94^{\circ} \mathrm{C}$ at 1 minute, Annealing $36^{\circ} \mathrm{C}$ at 1 minute, Extension $72^{\circ} \mathrm{C}$ at 2 minutes, Cycle 45 cycles, Final Extension $72{ }^{\circ} \mathrm{C}$ at 10 minutes. The band PCR-RAPD results were visualized with $2 \%$ gel agarose and were analyzed using Chi-square (cl: 95\%) were done with SPSS ver. 16.

\section{RESULTS AND DISCUSSION}

A total of 60 people from different individuals (30 positives for T2D \& 30 as control) were used to look for molecular markers on T2D. The primer used is D20 (5'-ACCCGGTCAC$\left.3^{\prime}\right)$. This study strengthens previous research that has shown polymorphism in T2D samples. ${ }^{19}$ Multiplication of samples and statistical analysis were carried out as well as looking for polymorphism characteristics from Sidoarjo, Indonesia.

PCR-RAPD produced 16 bands ranges from $174 \mathrm{bp}$ to $3677 \mathrm{bp}$ in length. Three bands were monomorphic (478 bp, $944 \mathrm{bp}, \& 2109 \mathrm{bp}$ ) and the others were polymorphic (Table 1). It was found that the band at $576 \mathrm{bp}$ was significantly different between controls and T2D ( $p$ value: 0.001 ). The number of bands found shows not the same number as the previous study. ${ }^{19}$ However, the lengths were found to be different. The differences in polymorphisms previously were found around $1500 \mathrm{bp}$.

Confirmation using statistical tests is needed for this study because Zahid ${ }^{19}$ studies $^{2}$ used a relatively small sample. With the use of more waste, the reliability and accuracy of the research can be accepted. However, RAPD requires a higher reliability test than other methods. The reason for the band appearance is one of the considerations for using the 
molecular marker. The clear of band target appearance above the monomorphic material is $476 \mathrm{bp}$ (Figure 1). This will make it easier to see. Based on the percentage, the value of the band that appears in the positive sample is still low, which shows that $40 \%$ or 12 people with T2D sufferers have this band. This value is still very small because the marker may use at least $80 \%$ of the sample to have this band.

Previous research shows differences in bands than this study. Six bands show the highest polymorphism where are not found in control samples but found in positive samples. The highest polymorphism is at around $1500 \mathrm{bp}$ in length. However, it was found to be far from the previous. The difference in results is possible because the specifications of each sample origin are different. ${ }^{17}$

The use of the 576 bp must be supported by other research that is mutually reinforcing. To strengthen the genes that are specifically involved, it needs to be confirmed. The use of the 576 bp must be supported by other research. To strengthen the genes that are specifically involved, it needs to be confirmed. The number of presence of 576 bp bands found was $40 \%$. The use of primers that produce different bands can give the best results.

PCR-RAPD analysis was impossible to identify genes specifically. PCR-RAPD method also produces many bands and most of its unnecessary. PCR-RAPD analysis is powerful when several primers that produce statistic significantly different polymorphisms are used together to detect the possibility of a person being exposed to T2D or not. it also can be used as a marker for screening associated gene T2D in certain populations. Validation is recommended for this method. Although a person is genetically at risk, the risk for each person to experience T2D and complications is different. ${ }^{19}$ The risk of T2D can be minimized by changing lifestyles. ${ }^{18}$ The weakness of this study is the limited information on the personal object detected, such as weight, another disease status, age, etc. so that a deeper discussion cannot be done.

\section{CONCLUSION}

The polymorphism analysis comparing T2D sample and controls found significant differences in the $576 \mathrm{bp}$ band ( $\mathrm{p}$-value 0.001 ) and can be used as candidates for molecular markers for these genetic disorders. The use of PCR-RAPD to molecular markers requires support for the other primers that produce specific bands.

\section{DISCLOSURE STATEMENT}

The authors declare that they have no conflict of interest.

\section{ACKNOWLEDGEMENT}

Our thanks go to DRPM UMSIDA who funded this research by internal grant 2020 and the molecular biology team who worked hard on the research. Molecular biology laboratory which has provided the facilities.

\section{FUNDING INFORMATION}

Internal grant.

\section{REFERENCES}

1. Saeedi P, Petersohn I, Salpea P, et al. Global and regional diabetes prevalence estimates for 2019 and projections for 2030 and 2045: Results from the International Diabetes Federation Diabetes Atlas, 9th edition. Diabetes Res Clin Pract. 2019;157:107843. doi:10.1016/i.diabres.2019.107843.

2. Alves C, Casqueiro J, Casqueiro J. Infections in patients with diabetes mellitus: A review of pathogenesis. Indian J Endocrinol Metab. 2012;16(7):27. doi:10.4103/22308210.94253.

3. Pititto B de A, Ferreira SRG. Diabetes and covid-19: more than the sum of two morbidities. Rev Saude Publica. 2020;54:54. doi:10.11606/s1518$\underline{8787.2020054002577 .}$ 
4. International Diabetes federation-IDF. Diabetes Atlas. 7th ed. Belgium: International Diabetes Federation; 2015. https://diabetesatlas.org/en/resources/.

5. Lyssenko V, Laakso M. Genetic Screening for the Risk of Type 2 Diabetes: Worthless or valuable? Diabetes Care. 2013;36(Supplement_2):S120-S126. doi:10.2337/dcS132009.

6. Karalliedde J, Gnudi L. Diabetes mellitus, a complex and heterogeneous disease, and the role of insulin resistance as a determinant of diabetic kidney disease. Nephrol Dial Transplant. 2014;31(2):gfu405. doi:10.1093/ndt/gfu405.

7. Mushlih M. Difference of Red Blood Cell Count (RBC) Levels in Diabetes Mellitus Type II with Ulcers and without Ulcers. J Ris Biol dan Apl. 2020;2(1):6-10.

8. Biadgo B, Melku M, Mekonnen Abebe S, Abebe M. Hematological indices and their correlation with fasting blood glucose level and anthropometric measurements in type 2 diabetes mellitus patients in Gondar, Northwest Ethiopia. Diabetes, Metab Syndr Obes Targets Ther. 2016;9:91. doi:10.2147/DMSO.S97563.

9. Hu C, Jia W. Diabetes in China: Epidemiology and Genetic Risk Factors and Their Clinical Utility in Personalized Medication. Diabetes. 2018;67(1):3-11. doi:10.2337/dbi17-0013.

10. Yu J. Genetics in Diabetes Mellitus - Contribution to the Classification and Management. Ann Pediatr Endocrinol Metab. 2012;17(4):211. doi:10.6065/apem.2012.17.4.211.

11. Andersson DK, Petersson C. Screening for Type 2 Diabetes. Diabetes Care. 2004;27(Supplement 1):S11-S14. doi:10.2337/diacare.27.2007.S11.

12. Chen J, Meng Y, Zhou J, et al. Identifying Candidate Genes for Type 2 Diabetes Mellitus and Obesity through Gene Expression Profiling in Multiple Tissues or Cells. J Diabetes Res. 2013;2013:1-9. doi:10.1155/2013/970435.

13. Ingelsson E, McCarthy MI. Human Genetics of Obesity and Type 2 Diabetes Mellitus. Circ Genomic Precis Med. 2018;11(6):2090. doi:10.1161/CIRCGEN.118.002090.

14. Tsaih S-W, Holl K, Jia S, et al. Identification of a Novel Gene for Diabetic Traits in Rats, Mice, and Humans. Genetics. 2014;198(1):17-29. doi:10.1534/genetics.114.162982.

15. van Tilburg J. Defining the genetic contribution of type 2 diabetes mellitus. J Med Genet. 2001;38(9):569-578. doi:10.1136/img.38.9.569.

16. Leitner DR, Frühbeck G, Yumuk V, et al. Obesity and Type 2 Diabetes: Two Diseases with a Need for Combined Treatment Strategies - EASO Can Lead the Way. Obes Facts. 2017;10(5):483-492. doi:10.1159/000480525.

17. Spanakis EK, Golden SH. Race/Ethnic Difference in Diabetes and Diabetic Complications. Curr Diab Rep. 2013;13(6):814-823. doi:10.1007/s11892-013-0421-9.

18. Asif $\mathrm{M}$. The prevention and control the type-2 diabetes by changing lifestyle and dietary pattern. J Educ Health Promot. 2014;3(1):1. doi:10.4103/2277-9531.127541.

19. Zahid RA, Sulaiman BK, Abd A, B. Molecular Investigation of Genetic Polymorphisms in Type 2 Diabetic Patients Using Random Amplified Polymorphic DNA (RAPD-PCR). Iraqi J Cancer Med Genet. 2011;4(2):47-54. https://www.iasj.net/iasj/article/56172.

\section{SHORT BIOGRAPHY}

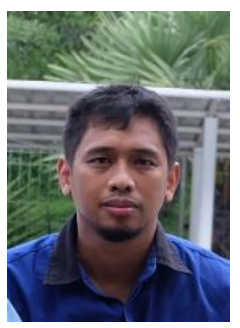

Miftahul Mushlih is genetics and molecular biology researcher who works at the Muhammadiyah University of Sidoarjo. Graduate from Gadjah Mada University. The research focuses on the optimization of molecular biology methods for the examination, detection of diseases and pathogens, and genetic markers of congenital disorders. 


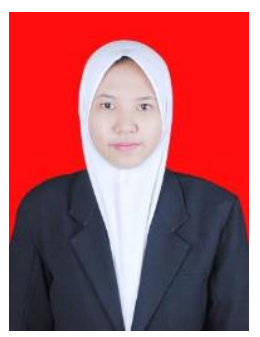

Fitri Khumala Sari. She worked as a COVID-19 aid worker at the Surabaya Class 1 Port Health Office.

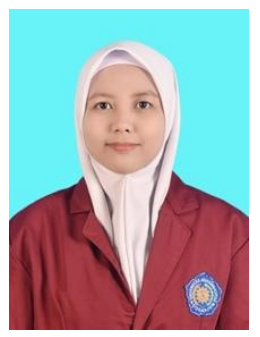

Hindah Sabrina Amin. She currently working at Asih Abyata Pasuruan's hospital.

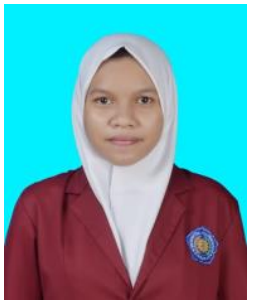

Siti Asriani Iknan. She working at the Bataraguru Public Health Center, Baubau City.

Tabel 1. Frequency of polymorphic bands in diabetics and control subjects based on D20 Primer

\begin{tabular}{ccccccc}
\hline \multirow{2}{*}{ No } & $\begin{array}{c}\text { Polymorphic band } \\
\text { size }(\mathrm{bp})\end{array}$ & \multicolumn{2}{c}{ Number of Sample } & \multicolumn{2}{c}{$\%$ Sample } & \multirow{2}{*}{ P-Value } \\
\cline { 3 - 6 } & 174 & Control & DMT2 & Control & DMT2 & \\
\hline 1 & 255 & 6 & 2 & 20.0 & 6.7 & 0.129 \\
2 & 3 & 10 & 23.3 & 33.3 & 0.390 \\
3 & 3 & 7 & 29 & 93.3 & 23.3 & 0.559 \\
4 & 353 & 28 & 27 & 86.7 & 96.7 & 0.554 \\
5 & 405 & 28 & 28 & 93.3 & 93.0 & 0.688 \\
6 & 476 & 1 & 12 & 3.3 & 40.0 & 0.001 \\
7 & 576 & 11 & 12 & 36.7 & 40.0 & 0.791 \\
8 & 623 & 27 & 28 & 90.0 & 93.3 & 0.640 \\
9 & 716 & 26 & 29 & 86.7 & 96.7 & 0.161 \\
10 & 784 & 29 & 29 & 96.7 & 96.7 & 1 \\
11 & 944 & 27 & 29 & 90.0 & 96.7 & 0.301 \\
12 & 1163 & 6 & 9 & 20.0 & 30.0 & 0.371 \\
13 & 1519 & 30 & 30 & 100.0 & 100.0 & 1 \\
14 & 2109 & 10 & 15 & 33.3 & 50.0 & 0.190 \\
15 & 2381 & 2 & 4 & 6.7 & 13.3 & 0.389 \\
16 & 3677 & & & & & \\
\hline
\end{tabular}




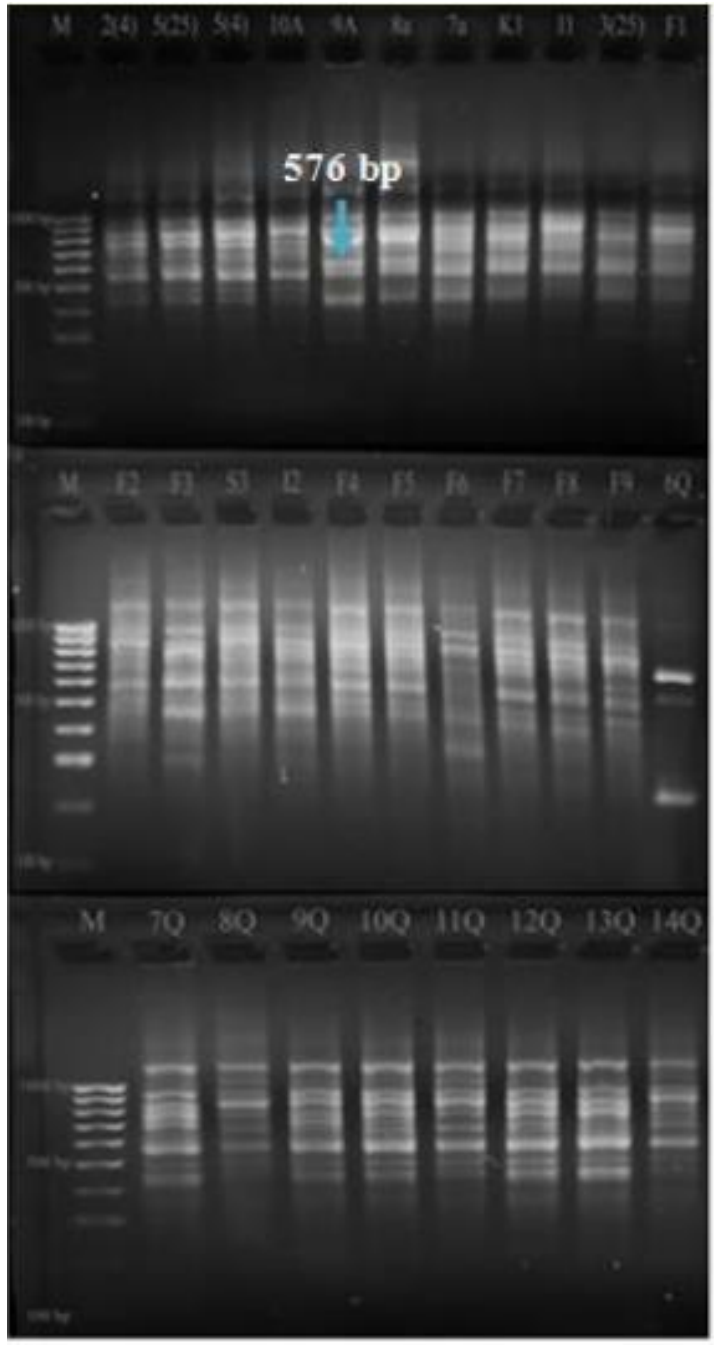

A

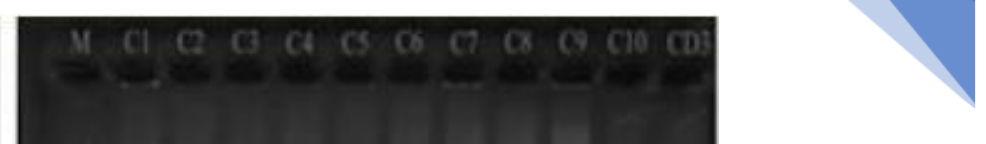

Figure 1. RAPD amplification products generated by primer D20. electrophoresis in $1.2 \%$

agarose gel, $\mathrm{M}$ is $100 \mathrm{bp}$ DNA ladder

B

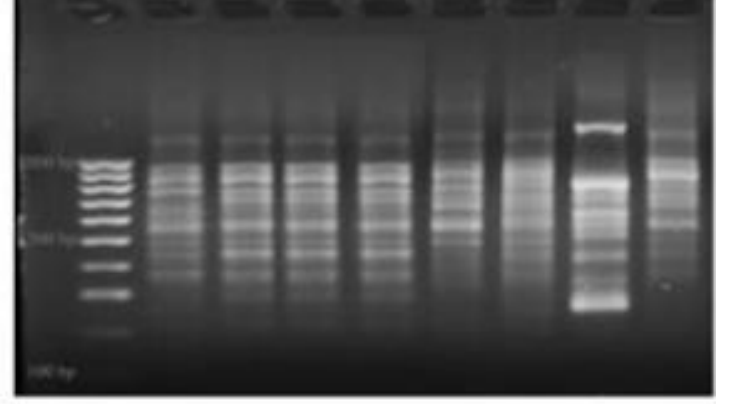

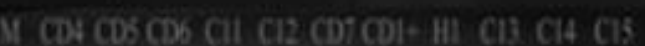

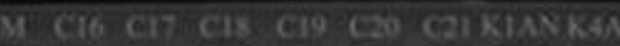

A: positive T2D, B: Control 